(C) 1992 ISIJ

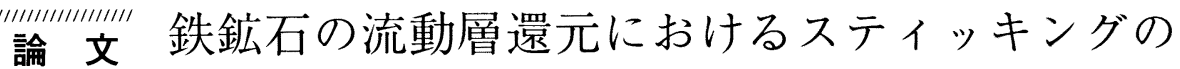 "IIIIIIIIIIII!" 発生機構とその防止法
}

\author{
宮川 一也 $*$.上條 綱雄 ${ }^{*}$. 出口 幹郎 ${ }^{* 2}$
}

\section{Sticking and Its Prevention in Fluidized Bed Reduction of Iron Ores}

Kazuya Miyagawa, Tsunao KamiJo and Mikio Deguchi

\section{Synopsis :}

Reduction of iron ore in a fluidized bed is limited by the agglomeration tendency of the bed particles, which causes defluidization. This defluidization is called 'Sticking phenomenon'.

In this paper, experimental studies using a batch-fluidized bed reactor are carried out to clarify the mechanism and the prevention method of sticking.

Following results are obtained.

1) Metallic iron wiskers which are generated on the surface of iron ore entangle the other particles and lead to sticking.

2) Sticking can be prevented by the carbon coating which restrains the growth of metallic iron whiskers.

3) If the metallic iron whiskers should grow, sticking can be prevented by controling the ratio of iron ore particles with wiskers below $50 \%$.

Key words : fluidized bed; defluidization; agglomeration; sticking; fine ore; metallic iron whisker; iron powder; carbon coating; mixing of non-sticking powder.

1. 緒言

粉状の鉄鉱石を直接利用する流動層還元には Elred ${ }^{1)}$, Plasmasmelt ${ }^{2)}, \mathrm{CIG}$ 法 $^{3)}$ 等の溶融還元製鉄法の予備 還元プロセスや H-Iron 法4), Nu-Iron 法 ${ }^{5)}$, FIOR

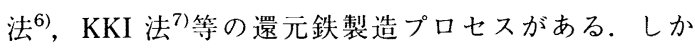
し，粉鉄鉱石の流動層還元において，還元途中で鉄鉱石 が凝集し，非流動化（Defluidization）に到る，いわゆ

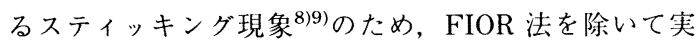
機規模の工業化に成功した例は少ない。スティッキング はシンタリング10)11) とも呼ばれており，鉄粉の焼結現 象の一種とも考えられていたが，その発生原因と機構に ついてはいまだ不明確な点が多い.

そこで, 本報では, 回分式小型流動層による基礎実

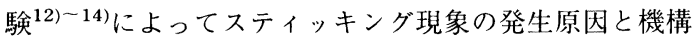
について検討し，その結果を基に安定した流動層還元を 行うためのスティッキング防止法について考察する.

\section{2. 実 験 方 法}

\section{$2 \cdot 1$ 実験装置}

実験に用いた回分式流動層の概略を Fig. 1 に示す. 本装置は電気炉による外熱式で住管の内径 $50 \mathrm{~mm}$ の 流動層反応器であり，アルミナボールを充填したガス予 熱炉を備えている. ガス分散板には孔径 $45 \mu \mathrm{m}$ のステ ンレス製メッシュフィルターを用いた。この分散板の下 側の中央部に直径 $10 \mathrm{~mm}$ のパイプが接続され, その上 側にストッパーがついている．ガス供給系には $\mathrm{N}_{2}$ 用と 還元ガス用の 2 系統があり, 瞬時に切り替えることがで きる. 流動層内の温度は分散板の上 $10,30 \mathrm{~mm}$ の 2 点で 上方から垂直に挿入した熱電対で測定した.

\section{$2 \cdot 2$ 限界還元率の評価}

還元実験は以下の要領で行った。まず，上部ホッパー から所定量の鉄鉱石を投入し, $\mathrm{N}_{2}$ で流動化する. その後, 流動層内が所定温度に達した後, 還元ガスに切り替え,

平成 3 年 11 月 8 日受付 平成 4 年 4 月 10 日受理（Received on Nov. 8, 1991; Accepted on Apr. 10, 1992)

* (株)神戸製銅所鉄鋼技術研究所 (Iron \& Steel Research Laboratories, Kobe Steel, Ltd., 2222-1 Ikeda Onoe-cho Kakogawa 675)

*2 (株)神戸製鎆所鉄鋼技術研究所 . T博 (Iron \& Steel Research Laboratories, Kobe Steel, Ltd.) 


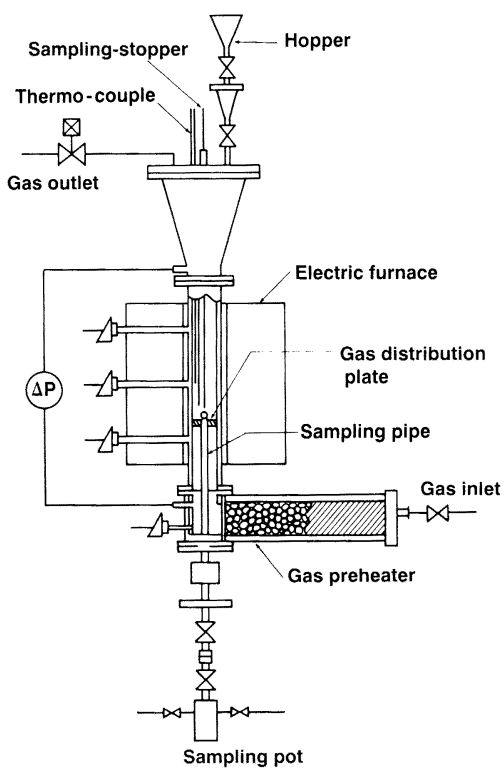

Fig. 1. Experimental apparatus for fluidized bed reduction.

$10 \mathrm{~min}$ 毎にストッパーを引き上げて流動層内から試料 2 〜 $\mathrm{g}$ を採取する. スティッキング検知後すぐに電気炉 を停止し，還元ガスを $\mathrm{N}_{2}$ に切り替えてスティッキング 発生時の状態を保持して $\mathrm{N}_{2}$ 冷却する. この還元率をス ティッキングが発生する限界の還元率とした，スティッ キングが生じない場合は $2 \mathrm{~h}$ で実験終了した.

\section{$2 \cdot 3$ スティッキングの検知法}

スティッキングは, 流動状態を文応管の差圧と流動層 内温度から検知した。すなわち, 反応管の上下間の差圧 は, 流動化状態では単位断面積当たりの鉄鉱石のホール ドアップ重量に等しいが, 非流動化によって急激に低下 する．また，流動化状態では固体粒子の混合によって流 動層内温度が均一であるが, 非流動化状態になると, ガ スの予熱温度が電気炉の温度より低いため流動層下部の 温度が上部の温度より約 $10^{\circ} \mathrm{C}$ 低くなる。これら, 差圧 と温度の変化からスティッキングを検知した。

\section{$2 \cdot 4$ スティッキング機構の検討}

スティッキングの発生原因を検討するために，8 種類 の鉄鉱石, 鉄粉, 炭素被覆鉄鉱石を用いて還元実験を行っ た. 以下に各実験の条件を示す.

8 種類の鉄鉱石の組成を Table 1 に示す．基準とし た実験条件は，溶融還元製鉄法の予備還元における石炭 ベースの還元ガスによる気泡流動層還元 ${ }^{15)}$ 想定して, 還元温度 $850^{\circ} \mathrm{C}$, ガス組成 $\mathrm{CO} / \mathrm{H}_{2}=80 / 20 \%$, ガス流
Table 1. Chemical composition of iron ore.

\begin{tabular}{c|c|c|c|c|c|c|c}
\hline \multirow{2}{*}{ Kind of ore } & \multicolumn{7}{|c}{ Chemical composition (mass\%) } \\
\cline { 2 - 8 } & $\mathrm{T} . \mathrm{Fe}$ & $\mathrm{FeO}$ & $\mathrm{SiO}_{2}$ & $\mathrm{Al}_{2} \mathrm{O}_{3}$ & $\mathrm{CaO}$ & $\mathrm{MgO}$ & $\mathrm{S}$ \\
\hline $\mathrm{A}$ & 62.31 & 0.46 & 5.82 & 1.26 & 0.15 & 0.13 & 0.024 \\
$\mathrm{~B}$ & 66.43 & 0.17 & 3.29 & 1.21 & 0.07 & 0.03 & 0.035 \\
$\mathrm{C}$ & 67.89 & 0.34 & 0.58 & 0.79 & 0.01 & 0.02 & 0.0074 \\
$\mathrm{D}$ & 68.06 & 0.17 & 1.05 & 0.29 & 0.02 & 0.01 & 0.0054 \\
$\mathrm{E}$ & 68.75 & 0.07 & 0.75 & 0.37 & 0.09 & 0.06 & 0.0039 \\
$\mathrm{~F}$ & 62.04 & 0.46 & 4.38 & 2.66 & 0.11 & 0.19 & 0.015 \\
$\mathrm{G}$ & 62.89 & 0.30 & 5.15 & 2.74 & 0.05 & 0.11 & 0.0048 \\
$\mathrm{H}$ & 56.85 & 18.57 & 2.96 & 3.68 & 1.51 & 3.55 & 0.0051 \\
\hline
\end{tabular}

Table 2. Ultimate analysis of coke.

\begin{tabular}{ccccc}
\hline $\mathrm{C}$ & $\mathrm{H}$ & $\mathrm{N}$ & $\mathrm{S}$ & Ash \\
\hline 81.0 & 0.4 & 0.9 & 0.5 & 12.0 \\
\hline
\end{tabular}

速 $0.4 \mathrm{~m} / \mathrm{s}$ とした. 還元実験の試料重量は $500 \mathrm{~g}$ とし, 鉄鉱石は 45〜 $500 \mu \mathrm{m}$ に整粒して用いた。一例として, 鉄鉱石 $\mathrm{A}$ の平均粒径（重量平均）は $120 \mu \mathrm{m}$ であり, 最小流動化開始速度 $\left(u_{m f}\right)$ は $0.08 \mathrm{~m} / \mathrm{s}$ である.

焼結現象に起因する非流動化を検討するために，ガス 流速 $0.2 \sim 0.6 \mathrm{~m} / \mathrm{s}$, 層内温度 $600 \sim 800^{\circ} \mathrm{C}$ で $\mathrm{N}_{2}$ 雲囲気 で鉄粉の流動層を用いた加熱実験を行った。鉄粉には， 水アトマイズ法で製造した重量平均径約 $70 \mu \mathrm{m}$ の鉄粉 を用いた。

スティッキングにおよぼす炭素被覆の影響を調べるた めに, 鉄鉱石 $\mathrm{A}$ を原料にして炭素被覆鉄鉱石を製造し た ${ }^{16)}$. 実験条件は 8 種類の鉄鉱石を用いた還元実験の 場合と同じである.

\section{$2 \cdot 5$ スティッキング防止法}

スティッキングにおよほす異種粒子添加の影響を検討 するために，鉄鉱石 A に粉コークス，鉄鉱石 $\mathrm{F}$ ，石灰 石粉を添加して還元実験を行った．粉コークスの組成を Table 2 に示す. 偏析を防止するために，粉コークスは 最小流動化開始速度が鉄鉱石とほぼ同じになるように, 粒度を $150 〜 200 \mu \mathrm{m}$ （平均粒径 $175 \mu \mathrm{m}$ ）に整粒した. 石灰石粉の場合も同様に偏析を防止するために，石灰石 粉の懸濁水溶液に鉄鉱石を浸漬し，乾燥して表面に付着 させた。

\section{3. 実 験 結 果}

\section{$3 \cdot 1$ スティッキングにおよぼす樴維状金属鉄の生成 の影響}

8 種類の鉄鉣石を用いた還元実験の結果を Fig. 2 に, 鉄鉱石銘柄とスティッキングが発生する限界の還元 率の関係を Table 3 に示す.これらよりスティッキン グを生じる鉄鉱石と生じない鉄鉱石に大別でき， ス ティッキングは還元率 30 ４0\% で生じることがわか 
る. 走査型電子顕微鏡で還元後の鉄鉱石粒子を観察する と，スティッキングした鉄鉱石 $\mathrm{A} ， \mathrm{~B} ， \mathrm{C} ， \mathrm{D} ， \mathrm{E}$ の表 面には鋭利な乫起物の形成が認められたが（Photo. 1-a))，スティッキングしなかった鉄鉱石 F， G，Hに は認められなかった (Photo. 1-b))。この笑起物は，全
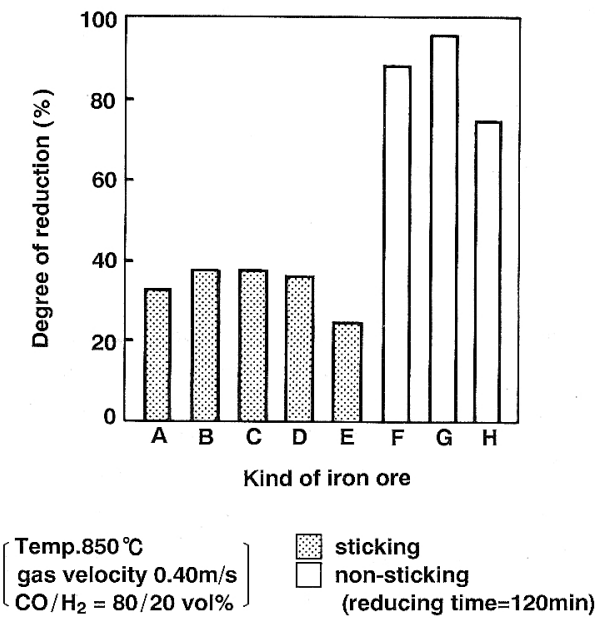

Fig. 2. Difference of sticking tendency among kinds of iron ore.

Table 3. Relationship between sticking and degree of reduction.

\begin{tabular}{|c|c|c|c|c|c|c|c|c|c|}
\hline \multirow{2}{*}{ Kind of ore } & \multicolumn{9}{|c|}{ Degree of reduction (\%) } \\
\hline & 10 & 20 & 30 & 40 & 50 & 60 & 70 & 80 & 90 \\
\hline $\begin{array}{l}\mathrm{A} \\
\mathrm{B} \\
\mathrm{C} \\
\mathrm{D} \\
\mathrm{E} \\
\mathrm{F} \\
\mathrm{G} \\
\mathrm{H}\end{array}$ & $\begin{array}{l}8 \\
8 \\
8 \\
8 \\
8 \\
8\end{array}$ & $\begin{array}{l}8 \\
8 \\
8 \\
8 \\
8 \\
8\end{array}$ & $\begin{array}{l}8 \\
8 \\
8 \\
\times \\
8 \\
8\end{array}$ & $\begin{array}{l}\times \\
\times \\
\times \\
\times \\
\times \\
\times \\
0 \\
8 \\
0 \\
0\end{array}$ & $\begin{array}{l}x \\
\times \\
\times \\
\times \\
\times \\
\times \\
0 \\
0 \\
0\end{array}$ & $\begin{array}{l}\times \\
\times \\
\times \\
\times \\
\times \\
\times \\
\bigcirc \\
8 \\
0\end{array}$ & $\begin{array}{l}x \\
\times \\
\times \\
\times \\
\times \\
\times \\
8 \\
8 \\
0\end{array}$ & 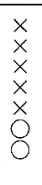 & $\begin{array}{l}\times \\
\times \\
\times \\
\times \\
\times \\
\stackrel{x}{0} \\
0\end{array}$ \\
\hline
\end{tabular}

体の還元率から考えて，ウスタイトから瀻維状に成長し た金属鉄 ${ }^{17118) て ゙ あ る と み な す こ と か ゙ て ゙ き る 。 ~}$

そこで，鉄鉱石 $\mathrm{A}$ について金属鉄が生成しない条件 (ガス組成 $\mathrm{CO} / \mathrm{CO}_{2}=50 / 50 \% ，$ 還元温度 $900^{\circ} \mathrm{C}$ ) で流 動層還元したところ，スティッキングせずに安定な流動 を $2 \mathrm{~h}$ 維持できた。このときの到達還元率は $27 \%$ であ り (Fig. 3), Photo. 1-c)に示すように突起物の形成は 認められなかった。これより，この突起物は瀻維状金属

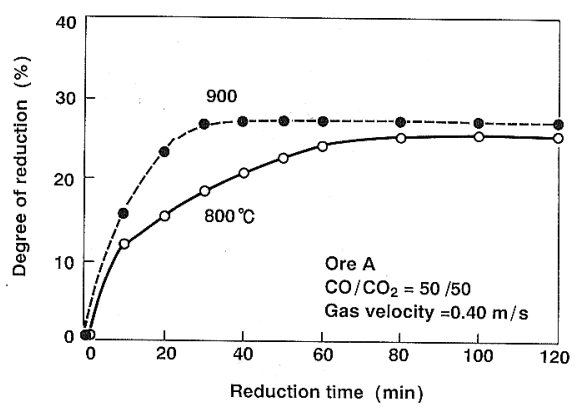

Fig. 3. Reduction behavior of iron ore in the condition of low reducing potential.

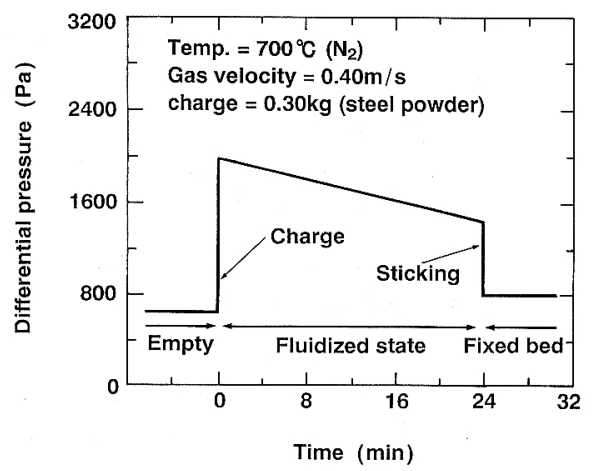

Fig. 4. Change of differential pressure in fluidized bed.
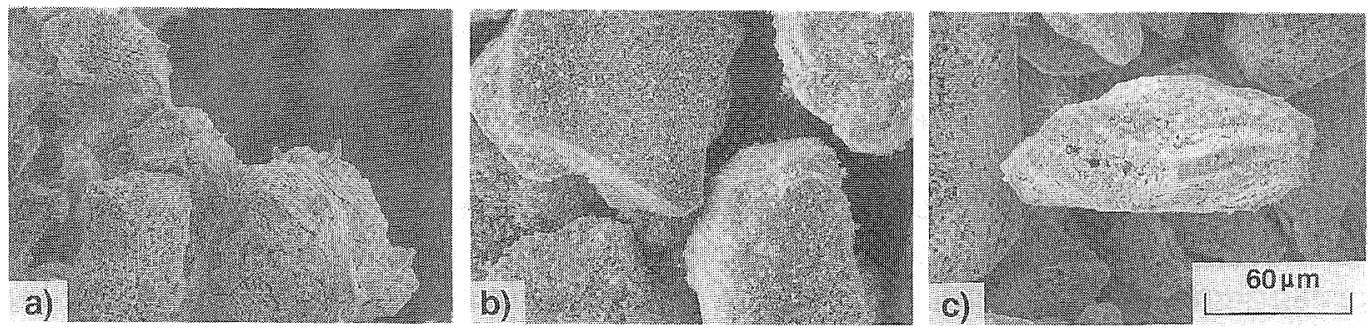

a) Ore A : Sticking at $R=35 \%\left(850^{\circ} \mathrm{C}, \mathrm{CO} / \mathrm{H}_{2}=80 / 20 \mathrm{vol} \%\right)$

b) Ore F : Non-sticking $R=94 \%\left(850^{\circ} \mathrm{C}, \mathrm{CO} / \mathrm{H}_{2}=80 / 20 \mathrm{vol} \%\right)$

c) Ore A : Non-sticking $R=26 \%\left(900^{\circ} \mathrm{C}, \mathrm{CO} / \mathrm{CO}_{2}=50 / 50 \mathrm{vol} \%\right)$

( $R:$ Degree of reduction)

Photo. 1. Variation of surface morphology after reduction in fluidized bed. 
鉄であり，鉄鉱不 $\mathrm{A} \sim \mathrm{E}$ のスティッキングは緎維状金 属鉄の作用によって生じたと推定される.

鉄粉を $\mathrm{N}_{2}$ 雲网気で $700^{\circ} \mathrm{C}$ に加熱した流動層に装入 した時の差変化を Fig. 4 に示す. 差厈は鉄粉の投入 㨁後から徐々に低下し，最後に非流動化に到った。この ときの䩧けの低下速度 $(\Delta P / \Delta t)$ に及ぼす流動層温度， 流動化ガス流速の影響を Fig. 5 に示す，通常，鉄粉粒 子が凝集していくと流動化している粒子が減少するた め, 流動層の差川は低下していく，そこで，差左の低下 速度を鉄粉精子のの凝集速度と見なして整理すると，凝集 は缯内温度に比例し，ガス流速に逆比例することがわか

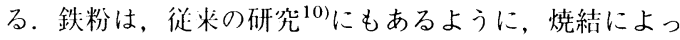
て粒子间士が㠜集し，非流動化したものとみなせる。

しかし, 鉄鈗价F，G，Hでは還元率 $90 \%$ 以上の粒 子表酒が完金に金属化した状態でも凝集せずに安定な流 動が維持されたが，その理由は次のように考えられる. 鉄鉱不の場令，還元の進行にともなって多孔質化し，見 掛け密度が鉄粉に比べて小さくなるので, 流動化し易い. さらに，粘子表面に $\mathrm{SiO}_{2}$ や $\mathrm{Al}_{2} \mathrm{O}_{3}$ 等の脈不が存在す ることにより，料子表泊の金禹鉄の比率が小さくなり， 金属鉄の焼絬による粒小间上の凝集が生じにくかったも のと考えられる。この脈不の凝集阴售作用によって鉄鉱 们 $\mathrm{F}$ H はスティッキングを牛じなかったと推定され る。しかし，䋐維状金属鉄が生成する場命は，脈石量が

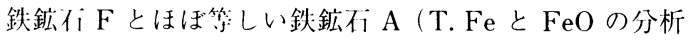
值から算刡して，条々 11.4 と $11.0 \%$ ) がスティッキン グを生じていることから，脈不の阻害作用では凝集を抑 制できなかったものと考えられる.

以トのことから，鉄鉣们の流動層還元におけるス

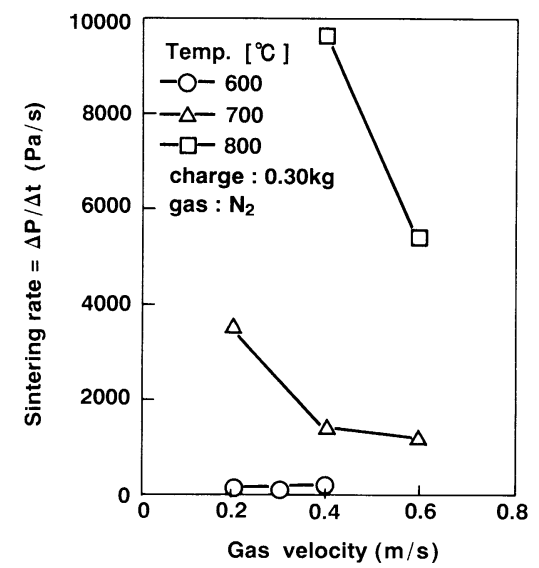

Fig. 5. Effect of gas velocity on sintering of iron powder in fluidized bed.
ティッキング現象は，金属鉄の焼結に起因する現象では なく, Photo. 1 に見られる繊維状金属鉄が絡み合う機 械的作用によるものであることがわかる.

そこで, 本報では纎維状金属鉄による非流動化をス ティッキング，金属鉄の焼結による非流動化をシンタリ ングと呼ぶ (Fig. 6).

繊維状金属鉄が絡み合って流動化しにくくなる現象 を，最小流動化開始速度の変化から検討した。鉄鈗石 $\mathrm{A}$ を $850^{\circ} \mathrm{C}$ で還元し，還元率 $35 \%$ でスティッキングし たものを解砕し， 100 300 $\mu \mathrm{m}$ の整粒した試料と，同じ 粒度の還元前試料の最小流動化開始速度を常温で測定し た（Fig. 7)。繊維状金属鉄が発生している還元後試料 の方が還元前試料よりも流動化開始速度が高くなってい ることから，この差は䋐維状金属鉄による流動化阻害作

(A) Low reduction level

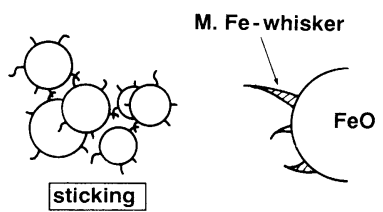

(B) High reduction level

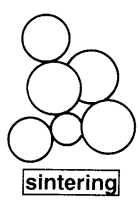

M. Fe-shell

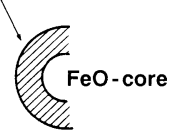

Fig. 6. Classification of defluidization (Sticking and sintering).

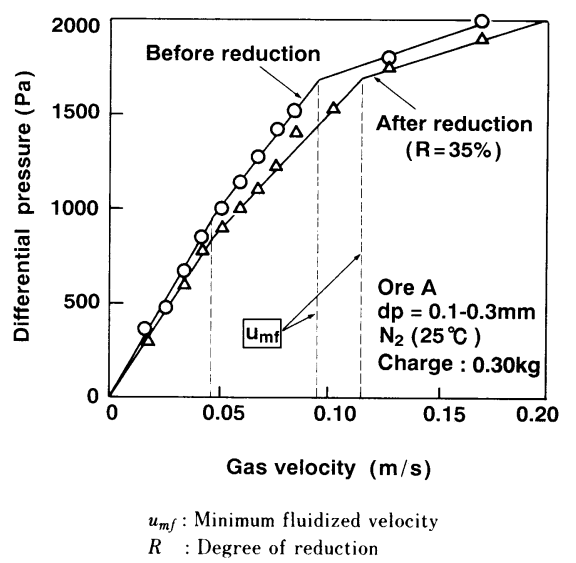

Fig. 7. Effect of particle surface state on fluidization. 
用を表しているとみなせる。

\section{$3 \cdot 2$ スティッキングにおよぼす炭素被覆の影響}

鉄鉱石粒子の表面を炭素被覆7することで流動層還元 ができることが知られている，本実験で用いた鉄鉱石の 炭素被覆法は，気相熟分解による炭素析出反応を利用し ており，炭素皮膜の厚みはほほ均一で，炭素被覆量に比 例するとみなせる。粒径 $120 \mu \mathrm{m} の$ 鉄鉱石において， $3.5 \%$ の炭素被覆量は約 $3.4 \mu \mathrm{m}$ の厚みの炭素皮膜とな 万.

スティッキングに及ぼす炭素被覆量の影響を Fig. 8 に，還元後の鉄鉱石粒子の表面状態をPhoto. 2 に示す. 炭素被㠅しない場合は，長い瀻維状金属鉄が成長してい る.しかし，炭素被覆量 $2.5 \%$ では炭素皮膜を突き破っ て，短い繊維状金属鉄が生成し，3.5\%では緎維状金属 鉄の生成は認められない。また，炭素被覆量 $2.5 \%$ で はスティッキングが生じたが, $3.5 \%$ では生じなかった。 このことから，炭素皮膜により繊維状金属鉄の生成が抑

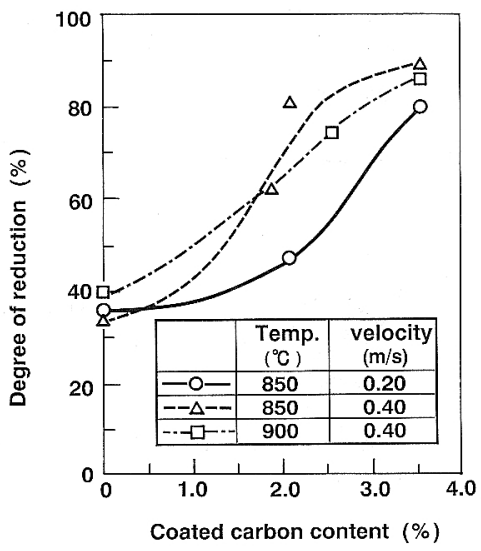

Fig. 8. Effect of coated carbon content on sticking of reduced iron ore.
制され，スティッキングが生じなかったことがわかる。

\section{3・3 スティッキングにおよぼす異種粒子添加の影響}

鉄鉱石 $\mathrm{A}$ に対し，粉コークス拉よび鉄鉱石 $\mathrm{F}$ を添加 して還元したときの，各々の添加量とスティッキングが 発生する限界の還元率の関係を Fig. 9 に示す．鉄鉱石 A に対して, 粉コークスは $35 \%$ 以上，鉄鉱石 F は $50 \%$ 以上添加することにより，スティッキングを完全に抑制 することができた。

粉コークス添加，鉄鉱石混合，ならびに炭素被覆鉄鉱 石の還元害験における還元後試料の凝集状態を Photo. 3 に示す。粉コータス添加の場合，コータス粒子と共に 鉄鉱石粒子が結合した擬似粒子のような凝集体が認めら れる，鉄鉱石混合の場合も，同様である。炭素被覆量 $2.5 \%$ の炭素被覆鉄鉱石の場合でも，スティッキングが 生じる以前に採取した試料中に同様の擬似粒子は確認で きた。

ここで, 流動層内の全粒子数に対する個数割合（[コー クス粒子の個数 $] /([$ 鉄鉱石粒子の個数 $]+[$ コークス粒子 の個数])）に換算すると、コークス添加率 35\%ははほぼ $50 \%$ に相当し，個数基準では鉄鉱石 $\mathrm{F}$ の場合と同じ值

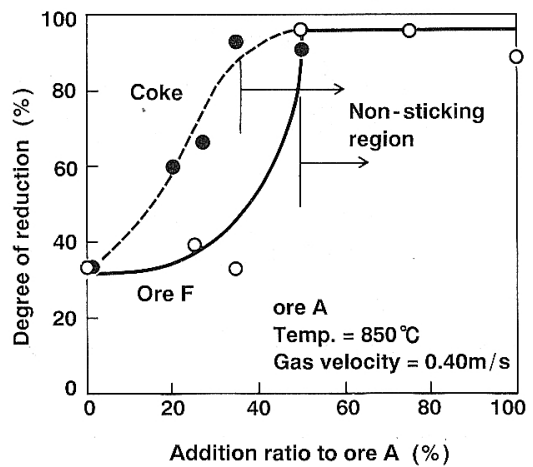

Fig. 9. Prevention of sticking by addition of nonsticking material.

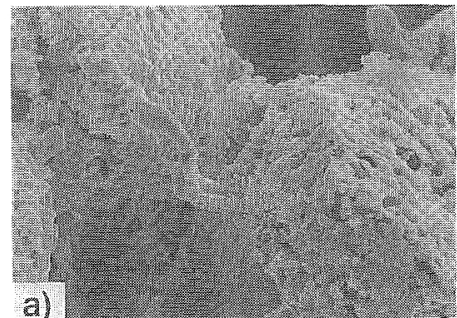

a)
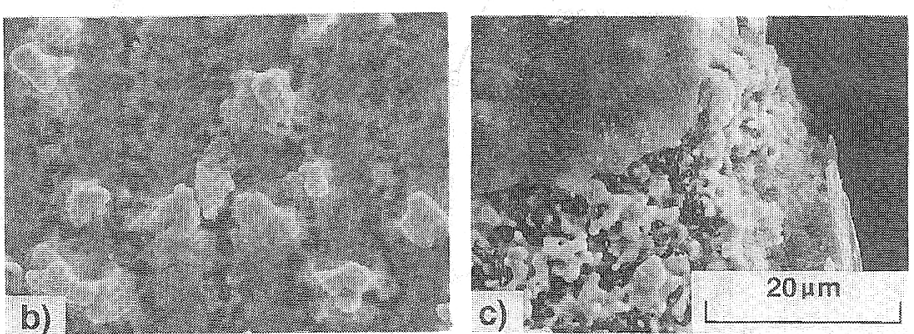

Ore A Temp. $=850^{\circ} \mathrm{C} \quad \mathrm{CO} / \mathrm{H}_{2}=80 / 20 \mathrm{vol} \%$

a) Without carbon coating

b) Carbon coating $2.5 \%-\mathrm{C}$

c) Carbon coating $3.5 \%-\mathrm{C}$

Photo. 2. Restricting effect of carbon coating on growth of $\mathrm{Fe}$-whisker. 


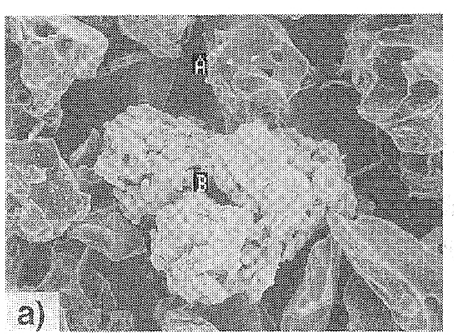

a)

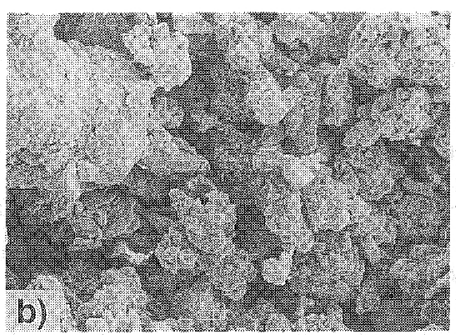

a) Addition of coke $(35 \mathrm{wt} \%)$

b) Addition of ore-F (50 wt \%)

c) Carbon coating $(3.5 \mathrm{wt} \%)$

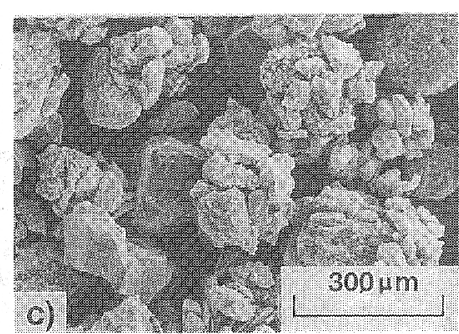

Photo. 3. Agglomerates grown up in fluidized bed.

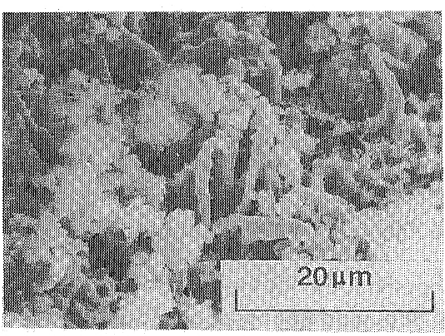

Photo. 4. Effect of $\mathrm{CaO}$ powder addition on growth of $\mathrm{Fe}$-whisker (Ore-A, $\mathrm{CaO}$ powder $=10 \%$ ).

になる。このことから，個数割合で全体の $50 \%$ 以上の 粒子に瀻維状金属鉄が発生すると, ステイッキングが生 じるとみなすことができる。

石灰石粉を付着させた場合, Photo. 4 に見られるよ うに石灰石粉の層を越えて繊維状金属鉄が成長し，還元 率 $35 \%$ でスティッキングが生じた。すなわち，微粉の 単純な表面付着はスティッキングの抑制には効果がない ことがわかる.

\section{4. 考察}

\section{$4 \cdot 1$ 緎維状金属鉄の生成}

緘維状金属鉄の成長の機構について, Nicolle $5^{18)}$ の $\mathrm{Fe}^{2+}$ 過飽和の理論によれば, ウスタイトの還元過程に 扔ける $\mathrm{Fe}^{2+}$ の固相搪散速度と還元速度の関係から, 生 成する金属鉄相の形状の違いは以下のように説明され る.

(1) 固相拡散速度が還元速度に比べて十分大きい場 合, $\mathrm{Fe}^{2+}$ の粒子内部への搪散によって大きな $\mathrm{Fe}^{2+}$ 過 飽和領域が形成され，臨界濃度を超えると一気に繊維状 に金属鉄が析出する。

( 2 )還元速度が固相搪散速度に比べて十分大きい場合 は, $\mathrm{Fe}^{2+}$ の過飽和領域が小さく, シェル状に金属鉄相
が形成される.

Photo. 3 に見られるように円錐形の瀻維状金属鉄が 生成していることから，本実験条件の還元では，上記の 機構( 1 ) ほどではないが, 固相拡散速度の方が還元速度 よりも大きい状況であると考えられる。

次に, 炭素被覆の䄉維状金属鉄生成の抑制効果につい て検討する. Photo. 3 を基に直径 $100 \mu \mathrm{m}$ の粒子に底辺 $4 \mu \mathrm{m}$, 高さ $10 \mu \mathrm{m}$ の円錐形の繊維状金属鉄が 12 本生 成し, $\mathrm{Fe}^{2+}$ の飽和領域が粒子表面から $10 \mu \mathrm{m}$ と仮定す ると, $\mathrm{Fe}^{2+}$ のウスタイトに対する過飽和度は $0.6 \%$ と なる。 小林ら ${ }^{17)}$ と同様に, Li らの ${ }^{19}$ 式

$$
R T \cdot \ln \left[C / C_{0}\right]=P V, C / C_{0}=1.006
$$

$R$ : ガス定数 $(\mathrm{J} / \mathrm{K} \cdot \mathrm{mol}), T$ : 温度 $(\mathrm{K}), P$ : 析出物 に対卞石压力 $(\mathrm{Pa}), V:$ 析出物のモル体積 $\left(\mathrm{m}^{3}\right), C$ : ウスタイト中の $\mathrm{Fe}^{2+}$ 浱度 $\left(\mathrm{mol} / \mathrm{m}^{3}\right), C_{0}$ : ウスタイト 中の $\mathrm{Fe}^{2+}$ の飽和濃度 $\left(\mathrm{mol} / \mathrm{m}^{3}\right)$

から析出物が受ける圧力を瀻維状の成長を引き起こす金 属鉄析出の応力とみなして求めると, $850^{\circ} \mathrm{C}$ で約 8.0 $\mathrm{MPa}$ となる. $1000^{\circ} \mathrm{C}$ 以下で生成方る低温気相熱分解 炭素は強度で 58 98 $\mathrm{MPa}$ ，基材との接着強度で 9 17 $\mathrm{MPa}$ であり 20121)，金属鉄析出の応力に比べて十分に大 きいため，炭素被覆によって繊維状金属鉄の成長が抑制 できたものと考无られる。

スティッキングの発生に及ほす寸鉄鉱石のアルミナ含有 量とイオウ含有量の影響を Fig. 10 に示す. $\mathrm{Al}_{2} \mathrm{O}_{3} / \mathrm{Fe}$ が 0.02 以上の鉄鉱石では, 瀻維状金属鉄が生成せず, スティッキングは生じていない.このことから瀻維状金 属鉄の発生は鉄鉱石中のアルミナ含有量に大きく依存す ることがわかる．重松ら ${ }^{22) に よ れ は ゙ ， ウ ス タ イ ト に ア ~}$ ルミナを添加すると，ウスタイト中にハーシナイト (Hercynite) が晶出し還元を促進する.したがって，ア ルミナ含有量の大きい鉄鉱石では, ハーシナイトの還元 促進効果によって還元速度が $\mathrm{Fe}^{2+}$ の固相搪散速度より 


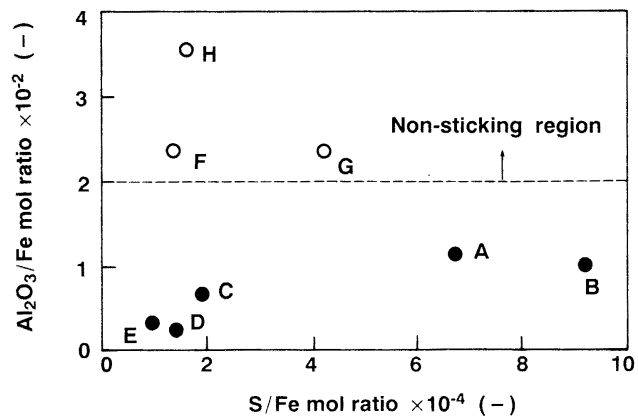

$\mathrm{A}-\mathrm{H}$ : Kind of ore

Fig. 10. Effect of slag composition on sticking.

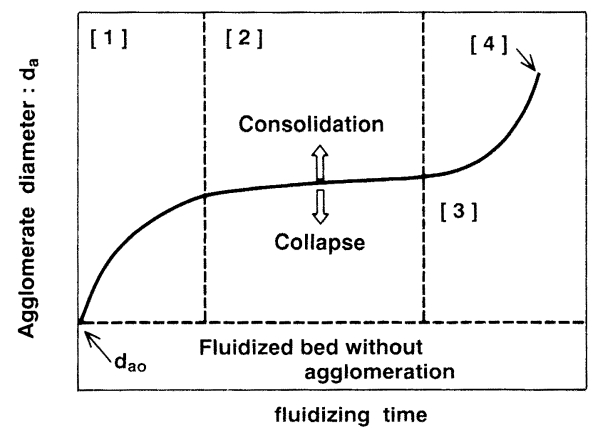
[1] First-formed agglomerating bed
[2] Dynamical equilibrium region
[3] Successive agglomerating bed
[4] Defluidization

Fig. 11. Growth model of agglomerates in a fluidized bed.

人きくなり，シェル状に金属鉄相が形成され，繊維状金 禹鉄は生成しないので，スティッキングは生じないと考 ネられる。

本実験条作の範网では，明暸なイオウの影響はみられ なかった。しかし, 従来の研究では鉄鉣们中のイウ由 来のガス状イオウの影響 ${ }^{23)}$ について報告されており， 今後の課題と考えられる.

\section{$4 \cdot 2$ スティッキング防止}

関口ら 24)の凝集モデル（Fig. 11）によれば，流動層 に扮いて粒子の凝集作用と崩壊作用が澛して，擬似粒 子化した凝集体の流動層が形成できると考えられる。そ の崩壊作用は流動層内での気泡の上昇による混命・攪汼 と凝集体同士の衝突からなる。

この考え方を異種粒于添加による還元尖験の結果に適 用すれば，流動層内での䋐維状金属鉄を発生した粒子の 做数割仓が全体の $50 \%$ 以下の制令では、Fig. 11 の[2]

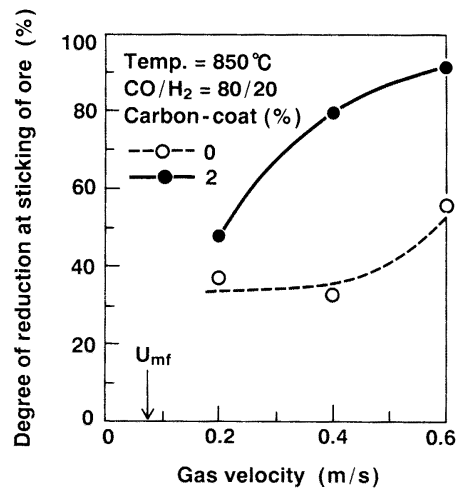

Fig. 12. Effect of gas velocity on sticking.

の領域における上記平衡状態にあり，50\%を超えると， 最小流動化開始速度に相当する档径以上に凝集体が成長 し，Fig. 11の[ 4]の位㯰における非流動化状態に到る.

このように凝集作用を低下させてスティッキングを抑 制する方法として, 䋐維状金属鉄を発生しない鉄鉣不や 粉コークス等の異種粒子の添加が们効であることを確認 した.

崩壊作用を高めてスティッキングを抑制するお法とし て，流動化ガス流速の増加の影響を検㗅したスティッ キングに及ぼす流動化ガス流速の影響を Fig. 12 に示 す。流速の増加にしたがって，隄界還元摔は上昇してい るが，いずれもスティッキングしている，测野ら25)ー27) によると気泡流動層の場介、流動粒子、に作用する力は最 小流動化開始速度の7〜8 倍程度でほぼ一分になるの で，ガス流速を $0.6 \mathrm{~m} / \mathrm{s}$ （最小流動化速度 $0.08 \mathrm{~m} / \mathrm{s} に$ 対して約 8 倍) 以上にしても，光䍱にスティッギングを 抑制することはできないと推定される。したがって，ガ ス流速增大で完全にスティッキングを抑制するために は，気泡流動化領域を越えて，乱流流動化あるいは高速 流動化の領域 ${ }^{28)}$ で流動蟹を操作し，粒于連動が不活発 な低速域を作らないことが必要であると考えられる。

\section{5. 結言}

鉄鈗不の流動層還元に㧍けるスティッキング現象の発 生原因とその機構を明らかにするため，回分式小型流動 層による還元实験を行った。その維果，以下のことが明 らかになった。

1 ) スティッキング現象は還元の進行にともなって牛 成する繊維状金属鉄が絡み仝うことによって生じること がわかった。

2 )繊維状金属鉄の!生成はアルミ十会在量の増大ある 
いは鉄鉱不表泊の炭素被覆によって抑制することができ る。

3)スティッキングを防止:するためには，繊維状金属 鉄を生成した粒子の割介が $50 \%$ 以下にする必要があ る。その才法として，䋐維状金属鉄を発生しない鉄鉱不 を混令するかあるいはコークス等の異種粒子の添加が有 効である。

\section{文献}

1) E. Bengtsson and B. Widell: Iron Steelmaker, 9 (1981) Oct., p. 30

2 ) S. Santen, J. Skoberg, S. Erikson and B. Johanssen: AIME Annual Convention in Pittsburg (1985 年 9 月)

3) 林 洋…鉄鋼笑, 34 (1984) 6, p. 76

4) R. A. Lubker and K. W. Bruland: J. Met., 12 (1960), p. 321

$5)$ T. F. Reed, J. G. Agarwal and E. H. Shipley: J. Met., 12 (1960), p. 317

$6)$ J. W. Brown, D. L. Campbell, A. L. Saxton and J. W. Carr, Jr.: J. Met., 18 (1966), p. 237

7 ) K. Mori, M. Onoda, R. Watanabe, R. Sugioka and K. Kaji: Conf. of SEAISI, Singapore (1984 年 9 月)

8 ) J. F. Grandsen, J. S. Sheasby and M. A. Bergougnou Chem. Eng. Prog. Simposium Series, 66 (1970) 105, p. 208

9 ) 大蔵明光: 鉄と鎡， 57 (1971), S8

10) J. G. Agarwal and W. L. Davis, Jr.: Chem. Eng. Prog. Symposium Series, 62 (1966) 67,p. 101
11) J. H. Siegell: Powder Technology, 38 (1984), p. 13

12）足永武彦，篠原克文，小野田守: 材料とプロセス, 1 (1988), p. 129

13）宫川一也, 上條網雄, 出口幹郎: 材料とプロセス, 1 (1988), p. 130

14）宮川一也，上條網雄，出口幹郎: 材料とプロセス，2(1989), p. 118

15) 森 憲二, 篠原克文, 竹中芳通, 上條網雄: 化学装置, 28 (1986)6, p. 99

16）篠原克文, 足永武彦, 上條䋞雄，出口幹郎，宮川一也， 竹中芳通: 材料とプロセス, 1 (1988),p. 131

17) 小林睦弘, H. W. グーデナウ, W. G. ブルヒャード, H. C. シェーファー: 鉄と鏏, 71 (1985), p. 1102

18) R. Nicolle and A. Rist: Metall. Trans. B, 10 (1979), p. 429

19) J. C. M. Li, R. A. Oriani and L. S. Darken: Zeitschr, Phy. Chem. Neue Folge, 49 (1966), p. 271

20）小島 昭，大谷杉郎，新藤一浩，扑上高志：日本化学会誌， (1982), p. 396

21) 小島 昭: 化学学, 52 (1988),p. 647

22）重松信一，希井彦哉: 鉄と鋼，73 (1987), p. 2243

23）林 昭二, 北川幹根, 井!義章: 材料とプロセス, 2(1989), p. 119

24）関口 勲, 辻本広行: シンポジゥム「新しい粉体材料の流 動層プロセッシング」(1988 年 11 月)

25) H. O. Kono, A. Soltani-ahmadi and M. Suzuki: Powder Technology, 52 (1987), p. 49

26) H. O. Kono and C. C. Huang: DOE/MC/23249-2397 (1987)

27) H. O. Kono and C. C. Huang: DOE/MC/23249-2502 (1987)

28）堀星正鞁: 化学装置, 28 (1986)6, p. 27 